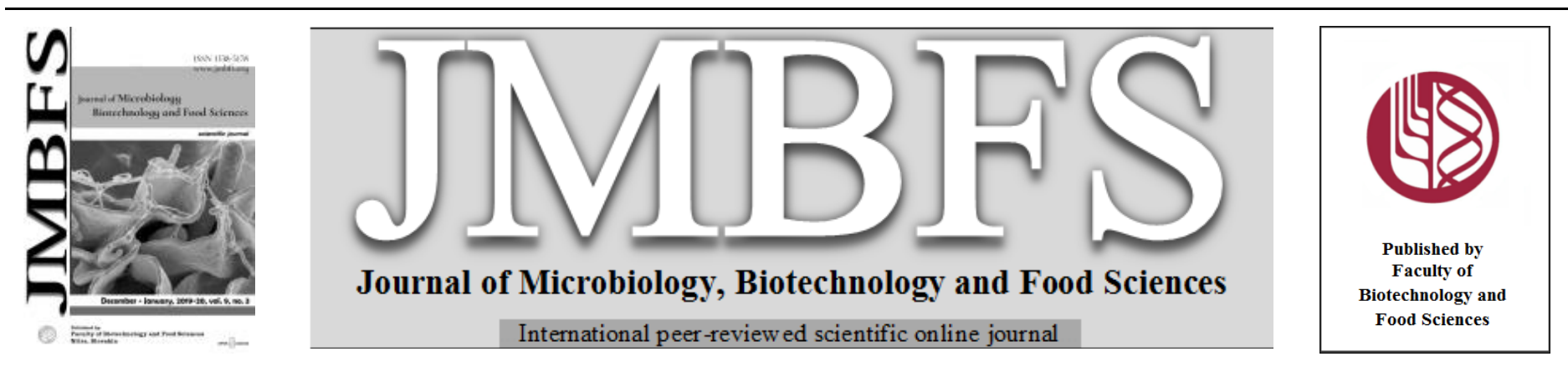

\title{
BIOCHEMICAL COMPOSITION AND FATTY ACID PROFILE OF THE MARINE MICROALGA Isochrysis galbana DRIED WITH DIFFERENT METHODS
}

\author{
Seyed Pezhman Hosseini Shekarabi ${ }^{*}$, Mehdi Shamsaie Mehrgan ${ }^{1}$, Niloofar Razi ${ }^{1}$, and Soheila Sabzi ${ }^{1}$
}

Address(es):

${ }^{1}$ Department of Fisheries Science, Science and Research Branch, Islamic Azad University, Tehran, Iran.

*Corresponding author: hosseini@ srbiau.ac.ir; hosseini.pezhman@yahoo.com

doi: 10.15414/jmbfs.2019/20.9.3.521-524

\section{ARTICLE INFO}

Received 16. 2. 2019

Revised 26. 4. 2019

Accepted 12. 5. 2019

Published 1. 12. 2019

Regular article open $\partial_{\text {Access }}$

\begin{abstract}
In this paper, the effects of different drying methods on proximate composition, pigment contents, and fatty acids profile of Isochrysis galbana were evaluated. The microalgae biomass was dried by freeze drying (FD), oven drying (OD), spray drying (SPD), and sun drying $(\mathrm{SD})$ methods to identify the best procedure with the lowest negative impacts on the algae nutrient values including pigments,

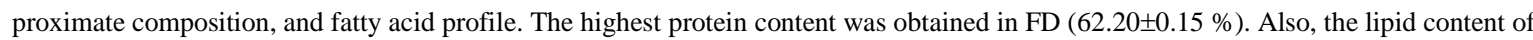
the dried microalga was significantly influenced by the drying process, while among all treatments, the highest and lowest values were measured in FD $(13.77 \pm 0.42 \%)$ and SD $(11.68 \pm 0.16 \%)$ samples, respectively $(\mathrm{P}<0.05)$. The highest chlorophyll $a(0.902 \pm 0.028$ $\mu \mathrm{g} / \mathrm{mg}), b(0.605 \pm 0.007 \mu \mathrm{g} / \mathrm{mg})$, and total carotenoids $(1.057 \pm 0.056 \mu \mathrm{g} / \mathrm{mg})$ were observed in FD samples. However, the lowest levels of chlorophylls and total carotenoid pigments were obtained in SD and SPD, respectively. The lipid profiling analysis showed the highest level of polyunsaturated fatty acids (PUFAs) in FD method (41.51\%), while the maximum saturated fatty acids were observed in SD (54.89\%) followed by OD (51.41\%). Also, the highest docosahexaenoic acid (12.41\%) were measured in FD compared to others $(\mathrm{P}<0.05)$. In conclusion, freeze drying method would be an efficient dewatering post-harvesting technique for the marine microalga $I$. galbana with the lowest impact on the nutritional quality in particular PUFAs content compared to the other studied drying methods.
\end{abstract}

\section{INTRODUCTION}

Microalga with a simple structure uses carbon dioxide and dissolved nutrient ions in water via sunlight for synthesis of different organic materials like pigments and other bioactive compounds (Pokoo-Aikins et al., 2010; Sabzi et al., 2018; Rastar et al., 2018). These microorganisms contain potential source of polyunsaturated fatty acids (PUFAs), and have been known as a promising renewable source of biofuel due to their high growth rate, low land usage and relatively high extractable oil yield (Chisti, 2007; Brennan and Owende, 2010; DalmasNeto et al., 2014; Sabzi et al., 2018). Furthermore, microalgae have been widely cultured and utilized as a live food in aquaculture industry (Welladsen $\boldsymbol{e t}$ al., 2014; Rastar et al., 2018)

Due to their unique nutritional values and health benefits, microalgae species are also being reconsidered in human diets (Chacón-Lee and González-Mariño, 2010, Vigani et al., 2015; FAO, 2016; Sabzi et al., 2018). However, ways of harvesting and dewatering of microalgal biomass are critical issues associated with the recovering of the nutritional components. Several commercial techniques including freeze, spray, and drum dryers of microalgae cultures have been employed (Chua and Chou, 2003; Grima et al., 2013; Chen et al., 2015) Among the various methods of drying, solar is commonly used procedure because of low cost and energy demands (Mata et al., 2010). However, this method may cause severe deterioration and denaturation of the valuable microalgae bio-products due to high microbial and biochemical spoilage rates during the drying process (Kumar et al., 2010; Grima et al., 2013; Stramarkou et al., 2017). In contrast, the freeze drying method has been shown to be the best technique due to high lipid yield and biodiesel quality of $C$. vulgaris (Hussain $\boldsymbol{e}$ al., 2015).

Marine microalgae, Isochrysis galbana is the best-known source of some essential nutrients, particularly PUFAs and is one of the most common species used for fish and shellfish larvae culture (Lin et al., 2007; Guihéneuf et al., 2009). There is little literature comparing the effects of different drying methods on microalgae nutritional value. Therefore, this study attempt to compare the effects of four different drying methods i.e. spray, oven, solar and freeze drying on nutritional composition and fatty acids profile of I. galbana.

\section{MATERIALS AND METHODS}

\section{Algae culture}

The initial purified seed of I. galbana was obtained from the Persian Gulf Biotechnology Park (Gheshm, Iran) and transported at Zakarya-e-Razi Laboratory Complex, IAU University (Tehran, Iran). The algae was grown in f2 medium (Guillard and Ryther, 1962) under culture conditions: $3511 \pm 351 \mathrm{IL}$ luminance (Lux) by fluorescent lamps, $\mathrm{pH} 8$, temperature $20 \pm 2{ }^{\circ} \mathrm{C}$, and $2.5 \%$ salinity. After 14 days of culture, the algae was harvested by using a Sigma 3 30KS centrifuge (Osterode, Germany) at $7100 \times \mathrm{g}$ for $15 \mathrm{~min}$ at $4^{\circ} \mathrm{C}$.

\section{Drying methods}

The fresh microalgal biomass $(120 \mathrm{~L})$ was dewatered using four different drying techniques: sun dried (SD) at $22-36{ }^{\circ} \mathrm{C}$ for 2 days, freeze dried (FD) at $-84^{\circ} \mathrm{C}$ under high vacuum conditions ( $0.04 \mathrm{mbar})$ for $12 \mathrm{~h}$ by a Christ Alpha $1-4$ freeze dryer (Christ, Germany), oven dried (OD) at $60{ }^{\circ} \mathrm{C}$ for $12 \mathrm{~h}$, and spray dried (SPD) (liquid suspension of algae) through a Buchi B-191 spray dryer (Buchi Laboratoriums-Technik AG, Switzerland) at $140-150{ }^{\circ} \mathrm{C}$ and $80-85^{\circ} \mathrm{C}$ as the inlet and outlet temperatures, respectively for 6-8 seconds.

\section{Chlorophyll $a, b$ and carotenoid contents}

Chlorophyll (Chl) contents of each treatment was determined using method described by Yang et al. (1998). Briefly, the dried samples (10 mg) were mixed with $5 \mathrm{~mL}$ of $80 \%$ acetone in a vortex for $5 \mathrm{~min}$, centrifuged at $1500 \times \mathrm{g}$ for 5 min, and the supernatant was collected. Chl $a, b$ and total carotenoid levels were measured using a Cary 50 UV-Vis spectrophotometer (Varian Inc., USA) at 663, 645 and $470 \mathrm{~nm}$, respectively (Porra et al. 1989; Holm 1954). The Chl $a, b$ and carotenoids contents were calculated by the following equations:

Chl $a(\mu g / m L)=12.25 \times A_{663}-2.25 \times A_{645}$ Chl $b(\mu g / m L)=20.31 \times A_{645}-2.25 \times A_{663}$ 


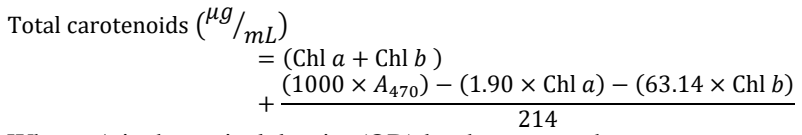

Where, A is the optical density (OD) by the spectrophotometer.

\section{Proximate composition}

Residual moisture in each sample ( $1 \mathrm{~g}$ ) was determined through an automatic moisture analyzer (Sartorius MA30, Germany) at $105^{\circ} \mathrm{C}$ for up to $60 \mathrm{~min}$ until reached a constant weight of the sample. Total protein was calculated $(\mathrm{N} \times 6.25)$ by the Kjeldahl method (AOAC, 2000). The extraction of total lipids was carried out in accordance with Bligh and Dyer (1959) method. Total ash content was calculated by a muffle furnace at $550^{\circ} \mathrm{C}$ for $8 \mathrm{~h}$.

\section{Fatty acids profile}

Fatty acids (FAs) composition of different dried samples were measured according to Cohen $\boldsymbol{e t}$ al. (1993) method and the results were expressed as \% of total fatty acids (TFAs). FAs were trans esterified in $2 \% \mathrm{H}_{2} \mathrm{SO}_{4}$-methano solution at $80^{\circ} \mathrm{C}$ for $1 \mathrm{~h}$, followed by adding n-heptane to the mixture prior to stirring and centrifugation at $2150 \times \mathrm{g}$ for $10 \mathrm{~min}$. Fatty acid methyl esters (FAMEs) were analyzed by a Younglin ACME 6100 Gas Chromatograph (Anyang, Korea) equipped with a mass selective detector (Dikmacap-2330), a capillary column DB-225JW (30 $\mathrm{m} \times 0.25 \mathrm{~mm} \times 0.25 \mu \mathrm{m})$, and helium used as the carrier gas with a flow rate of $2.6 \mathrm{~mL} / \mathrm{min}$. The injection temperature, ion temperature and interface temperature were set at 250,200 and $260{ }^{\circ} \mathrm{C}$, respectively, and the split ratio was 1:100.

\section{Statistical analysis}

All measurements were carried out in triplicates and the mean data and their standard errors were obtained. All variances were checked for normality and homogeneity, and one-way analysis of variance (ANOVA) was used to determine the significant difference in the dependent variables. Post-hoc Tukey-test at reliability level of 5\% was used to identify differences between each level of treatment.

\section{RESULTS}

\section{Changes in the biochemical composition}

Results of the proximate biochemical composition are summarized in Table 1. The highest protein $(62.20 \pm 0.15 \%)$ and moisture $(6.46 \pm 0.134 \%)$ contents were determined in FD and SD treatments, respectively. The Lipid content was significantly elevated in SPD samples $(\mathrm{P}<0.05)$. Also, minimum level of lipid content $(17.89 \pm 0.12 \%)$ was observed in FD samples. The highest and lowest ash content were obtained in FD $(13.77 \pm 0.42 \%)$ and SD $(11.68 \pm 0.16 \%)$, respectively.

Table 1 Proximate composition (\% in dry weight) of dehydrated Isochrysis galbana by different drying methods. OD: oven dried, FD: freeze dried, SD: sun dried, and SPD: spray dried.

\begin{tabular}{lcccc}
\hline \multirow{2}{*}{\begin{tabular}{c} 
Parameters \\
\cline { 2 - 5 }
\end{tabular}} & OD & FD & SPD & SD \\
\cline { 2 - 5 } Moisture & $3.94 \pm 0.29^{\mathrm{b}}$ & $4.03 \pm 0.14^{\mathrm{b}}$ & $4.10 \pm 0.22^{\mathrm{b}}$ & $6.46 \pm 0.134^{\mathrm{a}}$ \\
Protein & $60.08 \pm 0.53^{\mathrm{b}}$ & $62.20 \pm 0.15^{\mathrm{a}}$ & $60.53 \pm 0.38^{\mathrm{b}}$ & $60.10 \pm 0.41^{\mathrm{b}}$ \\
Lipid & $19.13 \pm 0.09^{\mathrm{b}}$ & $17.89 \pm 0.12^{\mathrm{c}}$ & $20.72 \pm 0.22^{\mathrm{a}}$ & $19.19 \pm 0.18^{\mathrm{b}}$ \\
Ash & $12.83 \pm 0.52^{\mathrm{b}}$ & $13.77 \pm 0.42^{\mathrm{a}}$ & $12.38 \pm 0.37^{\mathrm{b}}$ & $11.68 \pm 0.16^{\mathrm{c}}$ \\
\hline Mean values ( \pm standard error) followed by different letters in the same raw indicate a statistical difference $(\mathrm{n}=3, \mathrm{p}<0.05)$.
\end{tabular}

\section{Changes in the pigment contents}

As shown in Table 2, the highest content of Chl $a$ was obtained in FD $(0.902 \pm 0.028 \mu \mathrm{g} / \mathrm{mg})$ compared to other treatments $(\mathrm{P}<0.05)$. Also, the highest $\mathrm{Chl} \mathrm{b}$ was measured in FD $(0.605 \pm 0.007 \mu \mathrm{g} / \mathrm{mg})$, while the minimum value was obtained in SD $(0.490 \pm 0.004 \mu \mathrm{g} / \mathrm{mg})$. Further, the highest total carotenoid was obtained in FD $(1.057 \pm 0.056 \mu \mathrm{g} / \mathrm{mg})$, while SPD samples showed the minimum value $(0.735 \pm 0.028 \mu \mathrm{g} / \mathrm{mg})(\mathrm{P}<0.05)$.

Table 2 Pigment contents ( $\mu \mathrm{g} / \mathrm{mg}$ in dry weight) of dehydrated Isochrysis galbana by different drying methods. OD: oven dried, FD: freeze dried, SD: sun dried, and SPD: spray dried.

\begin{tabular}{|c|c|c|c|c|}
\hline \multirow{2}{*}{ Pigments } & \multicolumn{4}{|c|}{ Drying methods } \\
\hline & OD & FD & SPD & SD \\
\hline $\begin{array}{l}\text { Chlorophyll } \\
a\end{array}$ & $0.738 \pm 0.004^{\mathrm{bc}}$ & $0.902 \pm 0.028^{\mathrm{a}}$ & $0.776 \pm 0.014^{b}$ & $0.701 \pm 0.007^{\mathrm{c}}$ \\
\hline $\begin{array}{l}\text { Chlorophyll } \\
b\end{array}$ & $0.510 \pm 0.002^{\mathrm{b}}$ & $0.605 \pm 0.007^{\mathrm{a}}$ & $0.507 \pm 0.003^{\mathrm{b}}$ & $0.490 \pm 0.004^{\mathrm{c}}$ \\
\hline $\begin{array}{l}\text { Total } \\
\text { carotenoids }\end{array}$ & $0.844 \pm 0.049^{\mathrm{b}}$ & $1.057 \pm 0.056^{\mathrm{a}}$ & $0.735 \pm 0.028^{\mathrm{c}}$ & $0.849 \pm 0.014^{\mathrm{b}}$ \\
\hline
\end{tabular}

Table 3 Fatty acids profile (\% of total fatty acid) of dehydrated Isochrysis galbana by different drying methods. OD: oven dried, FD: freeze dried, SD: sun dried, and SPD: spray dried.

\begin{tabular}{|c|c|c|c|c|c|}
\hline \multirow{2}{*}{ Fatty acids } & & \multicolumn{4}{|c|}{ Drying methods } \\
\hline & & OD & FD & SPD & SD \\
\hline C8:0 & Caprylic acid & $0.18 \pm 0.01^{\mathrm{d}}$ & $0.51 \pm 0.02^{\mathrm{b}}$ & $1.00 \pm 0.03^{\mathrm{a}}$ & $0.27 \pm 0.02^{\mathrm{c}}$ \\
\hline C10:0 & Capric acid & $2.59 \pm 0.09^{\mathrm{b}}$ & $3.88 \pm 0.01^{\mathrm{a}}$ & $3.87 \pm 0.32^{\mathrm{a}}$ & $2.83 \pm 0.06^{\mathrm{b}}$ \\
\hline C12:0 & Lauric acid & $1.47 \pm 0.08^{\mathrm{c}}$ & $0.9 \pm 0.01^{\mathrm{d}}$ & $2.82 \pm 0.04^{\mathrm{a}}$ & $1.75 \pm 0.09^{\mathrm{b}}$ \\
\hline C14:0 & Myristic acid & $16.91 \pm 0.14^{\mathrm{a}}$ & $16.03 \pm 0.12^{\mathrm{b}}$ & $16.88 \pm 0.18^{\mathrm{a}}$ & $16.90 \pm 0.04^{\mathrm{a}}$ \\
\hline C15:0 & Pentadecylic acid & $1.88 \pm 0.01^{\mathrm{b}}$ & $1.27 \pm 0.01^{\mathrm{c}}$ & $1.98 \pm 0.16^{\mathrm{a}}$ & $1.91 \pm 0.01^{\mathrm{a}}$ \\
\hline C16:0 & Palmitic acid & $21.93 \pm 0.15^{\mathrm{a}}$ & $18.13 \pm 0.32^{\mathrm{b}}$ & $21.99 \pm 0.03^{\mathrm{a}}$ & $21.98 \pm 0.22^{\mathrm{a}}$ \\
\hline $\mathrm{C} 17: 0$ & Margaric acid & $0.15 \pm 0.04^{\mathrm{c}}$ & $0.32 \pm 0.01^{\mathrm{b}}$ & $0.48 \pm 0.01^{\mathrm{a}}$ & $0.50 \pm 0.05^{\mathrm{a}}$ \\
\hline C18:0 & Stearic acid & $1.06 \pm 0.01^{\mathrm{b}}$ & $0.91 \pm 0.04^{\mathrm{b}}$ & $2.48 \pm 0.33^{\mathrm{a}}$ & $1.05 \pm 0.01^{\mathrm{b}}$ \\
\hline C20:0 & Arachidic acid & $0.06 \pm 0.02^{\mathrm{c}}$ & $0.03 \pm 0.01^{\mathrm{c}}$ & $0.69 \pm 0.05^{\mathrm{a}}$ & $0.55 \pm 0.03^{b}$ \\
\hline $\mathrm{C} 21: 0$ & Heneicosylic acid & $1.19 \pm 0.05^{\mathrm{a}}$ & $0.08 \pm 0.01^{\mathrm{b}}$ & $0.07 \pm 0.02^{\mathrm{b}}$ & $1.09 \pm 0.01^{\mathrm{a}}$ \\
\hline $\mathrm{C} 22: 0$ & Behenic acid & $0.05 \pm 0.00^{\mathrm{b}}$ & $0.04 \pm 0.00^{\mathrm{b}}$ & $0.08 \pm 0.00^{\mathrm{a}}$ & $0.06 \pm 0.00^{\mathrm{a}}$ \\
\hline$\Sigma$ SFAs & & 52.41 & 42.10 & 52.34 & 54.89 \\
\hline C14:1 & Myristoleic acid & $0.18 \pm 0.01^{\mathrm{c}}$ & $0.49 \pm 0.06^{\mathrm{a}}$ & $0.38 \pm 0.05^{\mathrm{b}}$ & $0.45 \pm 0.04^{\mathrm{ab}}$ \\
\hline C16:1 & Palmitoleic acid & $3.63 \pm 0.06^{\mathrm{c}}$ & $7.76 \pm 0.05^{\mathrm{a}}$ & $2.79 \pm 0.17^{\mathrm{d}}$ & $5.55 \pm 0.19^{b}$ \\
\hline C17:1 & Heptadecenoc acid & $0.74 \pm 0.03^{\mathrm{b}}$ & $0.83 \pm 0.09^{\mathrm{a}}$ & $0.59 \pm 0.07^{\mathrm{c}}$ & $0.25 \pm 0.04^{\mathrm{d}}$ \\
\hline C20:1 & Eicosenoic acid & $0.72 \pm 0.02^{\mathrm{b}}$ & $0.34 \pm 0.01^{\mathrm{d}}$ & $0.96 \pm 0.07^{\mathrm{a}}$ & $0.5 \pm 0.05^{\mathrm{c}}$ \\
\hline $\mathrm{C} 24: 1$ & Nervonic acid & $0.037 \pm 0.01^{\mathrm{b}}$ & $0.05 \pm 0.01^{\mathrm{a}}$ & $0.04 \pm 0.01^{\mathrm{ab}}$ & $0.01 \pm 0.01^{\mathrm{c}}$ \\
\hline C18:1n-1 & Vaccenic acid & $1.52 \pm 0.1^{\mathrm{b}}$ & $1.2 \pm 0.01^{\mathrm{bc}}$ & $2.5 \pm 0.4^{\mathrm{a}}$ & $1.04 \pm 0.01^{\mathrm{c}}$ \\
\hline C18:1n-9 & Oleic acid & $12.31 \pm 0.04^{\mathrm{c}}$ & $16.50 \pm 0.09^{\mathrm{a}}$ & $15.13 \pm 0.17^{\mathrm{b}}$ & $11.51 \pm 0.06^{\mathrm{d}}$ \\
\hline$\Sigma$ MUFAs & & 16.32 & 20.98 & 19.39 & 16.31 \\
\hline C18:2 & Linoleic acid & $9.27 \pm 0.12^{\mathrm{c}}$ & $11.94 \pm 0.2^{\mathrm{a}}$ & $10.07 \pm 0.53^{b}$ & $9.87 \pm 0.13^{\mathrm{b}}$ \\
\hline C18:4 & Stearidonic acid & $9.13 \pm 0.22^{\mathrm{c}}$ & $14.41 \pm 0.3^{\mathrm{a}}$ & $9.68 \pm 0.29^{\mathrm{b}}$ & $9.08 \pm 0.03^{\mathrm{c}}$ \\
\hline C20:5 & Eicosapentaenoic acid & $1.06 \pm 0.00^{\mathrm{c}}$ & $2.75 \pm 0.04^{\mathrm{a}}$ & $2.06 \pm 0.02^{\mathrm{b}}$ & $1.05 \pm 0.00^{\mathrm{c}}$ \\
\hline $\mathrm{C} 22: 6$ & Docosahexaenoic acid & $8.12 \pm 0.07^{\mathrm{c}}$ & $12.41 \pm 0.08^{\mathrm{a}}$ & $9.9 \pm 0.06^{\mathrm{b}}$ & $8.52 \pm 0.25^{\mathrm{c}}$ \\
\hline$\Sigma$ PUFAs & & 27.58 & 41.51 & 31.71 & 28.52 \\
\hline
\end{tabular}




\section{Changes in fatty acids compositions}

FAs composition of dewatered I. galbana by different drying procedures is given in Table 3. Myristic acid (14:0) and palmitic acid (C16:0) were the most abundant saturated fatty acids (SFAs) which were the highest values in all treatments except for FD samples. Palmitoleic acid (C16:1) and oleic acid (C18:1) were mainly proportions of MUFAs, and the highest values was measured in FD treatment $(7.76 \pm 0.05 \%$ of TFAs and $16.50 \pm 0.09 \%$ of TFAs respectively). Linoleic acid (C18:2), stearidonic acid (C18:4) and docosahexaenoic acid (DHA) were the major fatty acids in PUFAs component Also, the highest linoleic acid $(11.94 \pm 0.20 \%$ of TFAs), stearidonic acid $(14.41 \pm 0.30 \%$ of TFAs), and DHA $(12.41 \pm 0.08 \%$ of TFAs) contents were obtain in FD samples compared to other treatments $(\mathrm{P}<0.05)$.

\section{DISCUSSION}

The results indicated that the highest protein content was obtained in FD method compared to other methods. The reason why a higher protein level was seen in FD samples compared to hot-air drying methods might be in part due to the loss of numerous nitrogen content with some volatile nitrogen based compounds which can leads to reducing of crude proteins content. However, FD probably preserve the protein content of microorganisms against direct heating. Stramarkou et al. (2017) reported higher content of protein and pigments in freeze-dried of $C$. vulgaris compared to hot-air dried samples. Furthermore, Desmorieux and Hernandez (2004) studied on the influence of different drying processes (convective, infrared drying, spray drying, and freeze drying) and compared proximate composition of dried Spirulina. Their results revealed that Freeze-drying showed the lowest protein.

Our results also showed that the moisture content in all treatments was less than $10 \%$ with the SD method showed the highest level. Therefore, it can be illustrated by high efficiency of drying methods in this study to dehydrate the algae cells.

The highest lipid content was measured in SPD followed by SD and OD samples, while the lowest amount of lipid was obtained by FD method. In a study by Hussain et al. (2015) the highest lipid level in $C$. vulgaris using OD drying method compared to FD methods due to more cell disruptions during oven drying period. Mass-transfer through the solid matrix is usually the rate-controlling step in extraction; and because of the lowest impact on demolishing of the microorganism's cell walls in FD method, the resistance to oil diffusion is higher than hot-air drying methods (Aguilera and Stanley, 1999; Gutiérrez et al., 2008). Similarly, Ryckebosch et al. (2012) indicated negligible impact of freezedrying on total lipids contents and FAMEs composition of Phaeodactylum tricornutum when it was compared with the fresh samples.

Total carotenoid and chlorophylls contents are important groups of primary metabolites in microalgae species which are highly affected by heating temperature and duration. FD method preserved a high level of Chl $a, b$ and carotenoids contents in I. galbana biomass after dewatering. A significant loss can be happened when the carotenoids are exposed to over $50^{\circ} \mathrm{C}$. Some investigators reported that algae species usually loss their crucial essentia nutrients such as carotenoids and chlorophylls during the dewatering process (Dey and Rathod, 2013). A marked reduction in total carotenoids of dewatered I. galbana was found in SPD due to the highest temperature in the drying process. Also, Ryckebosch et al. (2011) reported that the carotenoid content of the spray-dried microalga was significantly lower than that of the fresh and freeze-dried algae. This reduction may be explained by thermal breakdown and complexation of destroying carotenoids (Tang et al., 2000).

Hot-air drying usually destroys the cell structures, however, the primary structure and the shape of the microorganism's structures relatively stay protected in FD due to formation of the ice crystal inside the tissue matrix and the water get directly out from the solid to the gas phase, without any heating process (Youssef and Mokhtar, 2014). Also, heating process in conventionally dried techniques leads to accelerate the oxidation process of the dried microalgae biomass which can adversely impact on nutritional values and color of the final products (AnErl King et al., 2001; Güroy et al., 2017). Hsu et al. (2003) found that freezedrying method can preserve antioxidant activity of Dioscorea alata and $D$. purpurea. Also, Güroy et al. (2017) stated that employing a low-temperature technique in dewatering process may have positive effects on phycocyanin contents of $S$. platensis.

We found that myristic acid (C14:0), palmitic acid (C16:0), palmitoleic acid (C16:1), oleic acid (C18:1), linoleic acid (C18:2), stearidonic acid (C18:4), and docosahexaenoic acid (C22:6) were the most abundant fatty acids in all studied samples. Nonetheless, different drying methods affected the long chain unsaturated FAs, whereas OD and SD methods lead to loss of PUFAs levels. On the other hand, FD played an important contribution in resistance of PUFAs content. PUFAs are more susceptible to oxidation and rapidly lost under the high temperature conditions (Oehrl et al., 2001; Widjaja et al., 2009). Also, Balasubramanian et al. (2013) found that freeze-dried microalgae had the lowest value of free FAs. Therefore, our results indicated that the oven and sun drying methods of I. galbana are more suitable for biofuel production due to the highest content of SFAs. However, freeze drying was the best procedure to maintain MUFAs and PUFAs contents and proper for nutritional purposes.

\section{CONCLUSION}

We found that different drying methods had significant impact on some chemica and biochemical compositions, particularly fatty acids profile of I. galbana. The freeze-dried samples showed the highest level of protein, lipid, Chl $a, b$, and carotenoids, whereas the lowest levels were measured in sun drying method Also, our findings highlight that different drying methods not only could cause a different fat yield, but also could affect the total fatty acid production. The sundried biomass showed the highest content of SFAs, including C14:0 and C16:0, and the maximum level of MUFAs and PUFAs were obtained in the freeze-dried samples. The results confirmed that freeze drying method can provide a better preservation method compared to other dehydration methods with the lowest nutrient lost in I. galbana.

Conflict of interest: The authors declare that they have no conflict of interest.

Acknowledgement: We would like to thank the laboratory staffs at Science and Research Branch, Islamic Azad University (Tehran) for their valuable assistance and support.

\section{REFERENCES}

Aguilera, J. M., \& Stanley, D. W. (1999). Microstructural principles of food processing and engineering. Aspen Publishers, Gaitherburg, USA.

AOAC (2000). Approved methods of the American Association of Cereal Chemists. 17th Edition, American Association of Cereal Chemists, Inc., USA

Assman, A., Southard, S., John, S., Lei, A., \& Braun, A. (2011). The Potential for Micro-Algae and other" Micro-Crops" to Produce Sustainable Biofuels. University of Michigan, Michigan, USA.

Balasubramanian, R. K., Doan, T. T. Y., \& Obbard, J. P. (2013). Factors affecting cellular lipid extraction from marine microalgae. Chemical Engineering Journal, 215, 929-936. https://doi.org/10.1016/j.cej.2012.11.063

Bligh, E. G., \& Dyer, W. J. (1959). A rapid method of total lipid extraction and purification. Canadian Journal of Biochemistry and Physiology, 37(8), 911-917. https://doi.org/10.1139/o59-099

Brennan, L., \& Owende, P. (2010). Biofuels from microalgae-a review of technologies for production, processing, and extractions of biofuels and coproducts. Renewable and Sustainable Energy Reviews, 14(2), 557-577. https://doi.org/10.1016/j.rser.2009.10.009

Chacón-Lee, T. L., \& González-Mariño, G. E. (2010). Microalgae for "healthy" foods-possibilities and challenges. Comprehensive reviews in food science and food safety, 9(6), 655-675. https://doi.org/10.1111/j.1541-4337.2010.00132.x

Chen, C. L., Chang, J. S., \& Lee, D. J. (2015). Dewatering and drying methods for microalgae. Drying Technology, 33(4), 443-454.

Chen, C. Y., Yeh, K. L., Aisyah, R., Lee, D. J., \& Chang, J. S. (2011) Cultivation, photobioreactor design and harvesting of microalgae for biodiesel production: a critical review. Bioresource Technology, 102(1), 71-81. https://doi.org/10.1016/j.biortech.2010.06.159

Chisti, Y. (2007). Biodiesel from microalgae. Biotechnology Advances, 25(3), 294-306.

Chua, K. J., \& Chou, S. K. (2003). Low-cost drying methods for developing countries. Trends in Food Science \& Technology, 14(12), 519-528. https://doi.org/10.1016/j.tifs.2003.07.003

Cohen, Z., Norman, H. A., \& Heimer, Y. M. (1993). Potential use of substituted pyridazinones for selecting polyunsaturated fatty acid overproducing cell lines of algae. Phytochemistry, 32(2), 259-264. https://doi.org/10.1016/S00319422(00)94978-1

DalmasNeto, C. J., Sydney, E. B., Assmann, R., Neto, D., \& Soccol, C. R (2014). Production of biofuels from algal biomass by fast pyrolysis. In: Biofuels from Algae (pp. 143-153). Elsevier. https://doi.org/10.1016/B978-0-444-595584.00007-3

Desmorieux, H., \& Hernandez, F. (2004, August). Biochemical and physical criteria of Spirulina after different drying processes. In Proceedings of the 14th International Drying Symposium, São Paulo, Brazil.

Dey, S., \& Rathod, V. K. (2013). Ultrasound assisted extraction of $\beta$-carotene from Spirulina platensis. Ultrasonics Sonochemistry, 20(1), 271-276. https://doi.org/10.1016/j.ultsonch.2012.05.010

FAO (2016). The State of the World Fisheries and Aquaculture. Contribution to Food Security and Nutrition for All. Rome, Italy.

Grima, E. M., Fernández, F. A., \& Medina, A. R. (2004). 10 Downstream Processing of Cell-mass and Products. Handbook of microalgal culture: biotechnology and applied phycology, Garsington, UK

Guihéneuf, F., Mimouni, V., Ulmann, L., \& Tremblin, G. (2009). Combined effects of irradiance level and carbon source on fatty acid and lipid class composition in the microalga Pavlova lutheri commonly used in mariculture Journal of Experimental Marine Biology and Ecology, 369(2), 136-143. https://doi.org/10.1016/j.jembe.2008.11.009 
Guillard, R. R., \& Ryther, J. H. (1962). Studies of marine planktonic diatoms: I. Cyclotella nana Hustedt, and Detonula confervacea (Cleve) Gran. Canadian journal of microbiology, 8(2), 229-239. https://doi.org/10.1139/m62-029

Güroy, B., Karadal, O., Mantoğlu, S., \& Cebeci, O. I. (2017). Effects of different drying methods on C-phycocyanin content of Spirulina platensis powder. Ege Journal of Fisheries and Aquatic Sciences, 34(2), 129-132.

Gutiérrez, L. F., Ratti, C., \& Belkacemi, K. (2008). Effects of drying method on the extraction yields and quality of oils from quebec sea buckthorn (Hippophae rhamnoides L.) seeds and pulp. Food Chemistry, 106(3), 896-904. https://doi.org/10.1016/j.foodchem.2007.06.058

Holm, G. (1954). Chlorophyll mutations in barley. Acta Agriculturae Scandinavica, 4(1), 457-471

Hsu, C. L., Chen, W., Weng, Y. M., \& Tseng, C. Y. (2003). Chemical composition, physical properties, and antioxidant activities of yam flours as affected by different drying methods. Food chemistry, 83(1), 85-92. https://doi.org/10.1016/S0308-8146(03)00053-0

Hussain, J., Liu, Y., Lopes, W. A., Druzian, J. I., Souza, C. O., Carvalho, G. C., Nascimento, I. A., \& Liao, W. (2015). Effects of different biomass drying and lipid extraction methods on algal lipid yield, fatty acid profile, and biodiese quality. Applied Biochemistry and Biotechnology, 175(6), 3048-3057. https://doi.org/10.1007/s12010-015-1486-5

King, V. A. E., Liu, C. F., \& Liu, Y. J. (2001). Chlorophyll stability in spinach dehydrated by freeze-drying and controlled low-temperature vacuum dehydration. Food Research International, 34(2-3), 167-175. https://doi.org/10.1016/S0963-9969(00)00148-4

Kumar, A., Ergas, S., Yuan, X., Sahu, A., Zhang, Q., Dewulf, J., ... \& Van Langenhove, H. (2010). Enhanced CO2 fixation and biofuel production via microalgae: recent developments and future directions. Trends in biotechnology, 28(7), 371-380. https://doi.org/10.1016/j.tibtech.2010.04.004

Lin, Y. H., Chang, F. L., Tsao, C. Y., \& Leu, J. Y. (2007). Influence of growth phase and nutrient source on fatty acid composition of Isochrysis galbana CCMP 1324 in a batch photoreactor. Biochemical Engineering Journal, 37(2), 166-176. https://doi.org/10.1016/j.bej.2007.04.014

Mata, T. M., Martins, A. A., \& Caetano, N. S. (2010). Microalgae for biodiesel production and other applications: a review. Renewable and Sustainable Energy Reviews, 14(1), 217-232. https://doi.org/10.1016/j.rser.2009.07.020

Oehrl, L. L., Hansen, A. P., Rohrer, C. A., Fenner, G. P., \& Boyd, L. C. (2001)

Oxidation of phytosterols in a test food system. Journal of the American Oil Chemists' Society, 78(11), 1073-1078.

Oliveira, E. G. D., Rosa, G. S. D., Moraes, M. A. D., \& Pinto, L. A. A. (2008) Phycocyanin content of Spirulina platensis dried in spouted bed and thin layer Journal of Food Process Engineering, 31(1), 34-50 https://doi.org/10.1111/j.1745-4530.2007.00143.x

Pokoo-Aikins, G., Nadim, A., El-Halwagi, M. M., \& Mahalec, V. (2010). Design and analysis of biodiesel production from algae grown through carbon sequestration. Clean Technologies and Environmental Policy, 12(3), 239-254. https://doi.org/10.1007/s10098-009-0215-6

Porra, R. J., Thompson, W. A., \& Kriedemann, P. E. (1989). Determination of accurate extinction coefficients and simultaneous equations for assaying chlorophylls a and b extracted with four different solvents: verification of the concentration of chlorophyll standards by atomic absorption spectroscopy. Biochimica et Biophysica Acta (BBA)-Bioenergetics, 975(3), 384-394. https://doi.org/10.1016/S0005-2728(89)80347-0

Rastar, M., Hosseini Shekarabi, S. P., Shamsaie Mehrgan, M. S., \& Sabzi, S. (2018) Effects of iron and zinc concentrations on growth performance and biochemical composition of Haematococcus pluvialis: a comparison between nanoparticles and their corresponding metals bulks. Journal of Algal Biomass Utilization, 9, 59-67

Ryckebosch, E., Muylaert, K., \& Foubert, I. (2012). Optimization of an analytical procedure for extraction of lipids from microalgae. Journal of the American Oil Chemists' Society, 89(2), 189-198. https://doi.org/10.1007/s11746-011-1903-z Sabzi, S., Shamsaie Mehrgan, M., Rajabi Islami, H., \& Hosseini Shekarabi, S. P. (2018). Changes in biochemical composition and fatty acid accumulation of Nannochloropsis oculata in response to different iron concentrations. Biofuels, 1 7. https://doi.org/10.1080/17597269.2018.1489672

Santo, E. F. D. E., Lima, L. K. F. D., Torres, A. P. C., Oliveira, G. D., \& Ponsano, E. H. G. (2013). Comparison between freeze and spray drying to obtain powder Rubrivivax gelatinosus biomass. Food Science and Technology, 33(1), 47-51. http://dx.doi.org/10.1590/S0101-20612013005000008

Sharma, K. K., Garg, S., Li, Y., Malekizadeh, A., \& Schenk, P. M. (2013). Critical analysis of current microalgae dewatering techniques. Biofuels, 4(4), 397-407.

Singh, B., Guldhe, A., Rawat, I., \& Bux, F. (2014). Towards a sustainable approach for development of biodiesel from plant and microalgae. Renewable and Sustainable Energy Reviews, 29, 216-245. https://doi.org/10.1016/j.rser.2013.08.067

Stramarkou, M., Papadaki, S., Kyriakopoulou, K., \& Krokida, M. (2017). Effect of drying and extraction conditions on the recovery of bioactive compounds from Chlorella vulgaris. Journal of Applied Phycology, 29(6), 2947-2960. https://doi.org/10.1007/s10811-017-1181-8
Tang, Y. C., \& Chen, B. H. (2000). Pigment change of freeze-dried carotenoid powder during storage. Food Chemistry, 69(1), 11-17. https://doi.org/10.1016/S0308-8146(99)00216-2

Vigani, M., Parisi, C., Rodríguez-Cerezo, E., Barbosa, M. J., Sijtsma, L., Ploeg, M., \& Enzing, C. (2015). Food and feed products from micro-algae: Market opportunities and challenges for the EU. Trends in Food Science \& Technology, 42(1), 81-92. https://doi.org/10.1016/j.tifs.2014.12.004

Welladsen, H., Kent, M., Mangott, A., \& Li, Y. (2014). Shelf-life assessment of microalgae concentrates: effect of cold preservation on microalgal nutrition $\begin{array}{llll}\text { profiles. } & \text { Aquaculture, } & \text { 241-247. }\end{array}$ https://doi.org/10.1016/j.aquaculture.2014.04.016

Widjaja, A., Chien, C. C., \& Ju, Y. H. (2009). Study of increasing lipid production from fresh water microalgae Chlorella vulgaris. Journal of the Taiwan Institute of Chemical Engineers, 40(1), 13-20. https://doi.org/10.1016/j.jtice.2008.07.007

Yang, C. M., Chang, K. W., Yin, M. H., \& Huang, H. M. (1998). Methods for the determination of the chlorophylls and their derivatives. Taiwania, 43(2), 116122. http://dx.doi.org/10.6165/tai.1998.43(2).116

Youssef, K. M., \& Mokhtar, S. M. (2014). Effect of drying methods on the antioxidant capacity, color and phytochemicals of Portulaca oleracea L. leaves. Journal of Nutrition \& Food Sciences, 4(6), 1-6. http://dx.doi.org/10.4172/2155$\underline{9600.1000322}$ 